\title{
EFEKTIVITAS PEMBELAJARAN \\ VALUE CLARIFICATION TECHNIQUE (VCT) BERBANTU MEDIA VIDEO INTERAKTIF DITINJAU DARI HASIL BELAJAR PKN
}

\author{
Risania Wijayanti \\ Program Studi PGSD \\ FKIP - Universitas Kristen Satya Wacana \\ Wasitohadi \\ wasitohadiuksw@gmail.com \\ Program Studi PGSD \\ FKIP - Universitas Kristen Satya Wacana
}

\begin{abstract}
ABSTRAK
Latar belakang masalah dalam penelitian ini adalah bahwa proses pembelajaran PKn yang dilakukan guru cenderung menggunakan model konvensional dengan menerapkan metode ceramah. Dengan model tersebut, guru cenderung tidak memberikan pemahaman nilai-nilai yang ada pada pembelajaran PKn. Dari latar belakang itu peneliti akan menguji tingkat efektivitas penggunaan pembelajaran VCT berbantu video interaktif dengan model konvensional berbantu video interaktif. Tujuan penelitian ini untuk mengetahui apakah ada perbedaan antara efektivitas model konvensional ceramah berbantu media video interaktif dan pembelajaran VCT berbantu media video interaktif terhadap hasil belajar PKn siswa kelas 5 SDN Mangunsari 03 Salatiga semester II tahun pelajaran 2014/2015.Jenis penelitian yang digunakan dalam penelitian ini adalah eksperimen dengan metode penelitian quasi eksperimental. Desain penelitian yang digunakan adalah pretest-posttest control group design. Subjek penelitian ini sebanyak 57 siswa. Teknik pengumpulan data yang digunakan adalah dengan tes dan observasi. Teknik analisis data menggunakan independent sample $\mathrm{t}$ test. Hasil penelitian menunjukkan bahwa ada perbedaan efektivitas antara pembelajaran VCT berbantu media video interaktif dan model konvensional ceramah berbantu media video interaktif terhadap hasil belajar PKn siswa kelas 5 SDN Mangunsari 03 Salatiga semester II tahun pelajaran 2014/2015 terbukti. Hal ini ditunjukkan hasil uji t sebesar 2,072> 2,00404 dan signifikansi sebesar 0,043<0,05.
\end{abstract}

Kata kunci: Pembelajaran VCT, Media Video Interaktif, Hasil Belajar PKn

\section{PENDAHULUAN}

Persoalan pendidikan selalu saja sangat menarik untuk diperbincangkan dan dibahas di setiap zaman. Tidak saja karena persoalan pendidikan atau yang lebih spesifik mendidik, selalu merupakan tugas para guru, orang tua atau mereka yang berhubungan langsung dengan dunia pendidikan, namun persoalan pendidikan telah menjadi polemik manusia dari generasi ke generasi. Tentang bagaimana sebuah proses pendidikan dilangsungkan, dari masa ke masa selalu akan dicari suatu bentuk proses pendidikan yang memungkinkan proses pendidikan mencapai hasil yang diinginkan dan sesuai tuntutan zaman. Berkaitan dengan hal itu, persoalan materi atau isi bahan dan sarana pendidikan 
yang memungkinkan tercapainya tujuan pendidikan adalah menjadi tugas utama dari mereka yang berhubungan langsung dengan pengambilan kebijakan dan pelaksana kurikulum pendidikan.

Dalam ketercapaian tujuan pendidikan tentu juga mengarah pada dunia pendidikan yang semakin maju dan mengglobal. Salah satunya pembelajaran karakter sangatlah penting bagi siswa, guna memberikan filter atau bekal dalam menghadapi tantangan globalisasi. Terutama pada pendidikan kewarganegaraan (selanjutnya akan ditulis PKn) di SD. PKn merupakan salah satu dari beberapa mata pelajaran yang diajarkan di dalam Kurikulum Tingkat Satuan Pendidikan Sekolah Dasar. Tujuan dari PKn di SD yaitu memberikan pengetahuan kepada siswa tentang peristiwa-peristiwa ataupun kejadiankejadian untuk dianalisa agar nantinya siswa dapat mengambil teladanan dan juga mengambil sikap atas masalah yang terjadi di dalam lingkungan sekitar, sehingga terbentuk siswa yang berbudi pekerti dan bermoral pancasila. Sikap cenderung mengarah pada perasaan dan perbuatan dari diri seseorang yang sangat berhubungan dengan minat, nilai, penghargaan, pendapat dan prasangka.

Sesuai dengan tujuan PKn di atas, bahwa pemahaman materi serta pemahaman nilai melalui proses pembelajaran bukan hal yang mudah, melainkan cukup sulit sehingga membutuhkan model pembelajaran yang tepat. Pembelajaran PKn selama ini terkendala oleh banyaknya materi yang harus disampaikan guru kepada siswa, waktu belajar PKn yang sangat minim, dan rendahnya kemampuan guru dalam pemahaman nilai-nilai yang ada pada pembelajaran PKn.

Berdasarkan hasil observasi di SDN Mangunsari 03, proses pembelajaran PKn yang dilakukan guru cenderung mengguna- kan model konvensional yang belum dioptimalkan, seperti metode ceramah yang hanya menyampaikan atau menuntaskan dan menghafalkan materi PKn yang padat kepada siswa tanpa memberikan pemahaman nilainilai yang ada pada pembelajaran PKn.

Menurut Mc. Leish (PPPG IPS dan PMP Malang, 2006:49) keberhasilan metode ceramah tergantung harapan siswa. Jika siswa menyukai, maka penggunaan metode ceramah akan berfaedah, sebaliknya jika siswa tidak menyukai, maka penggunaan metode ceramah akan menemui kegagalan. Sehingga memicu anggapan siswa bahwa PKn merupakan mata pelajaran yang mudah dan hanya menghafal. Dari anggapan siswa yang demikian justru akan membuat bumerang bagi diri siswa yang mengakibatkan karakter yang harus terbentuk sesuai tujuan pembelajaran PKn menurun sehingga akan berdampak pada hasil belajar siswa.

Dalam proses pembelajaran PKn tentunya sangatlah mungkin bagi para pendidik khususnya guru memahami karakteristik peserta didik serta lebih memaksimalkan model, media dan strategi pembelajarannya. Dengan demikian proses pembelajaran akan lebih variatif, dan inovatif dalam merekonstruksikan pengetahuan sehingga dapat meningkatkan aktivitas dan kreatifitas belajar peserta didik. Untuk membantu siswa memahami konsep dalam pembelajaran PKn tersebut dengan model pembelajaran Value Clarification Technique (yang seterusnya akan ditulis VCT) dalam proses pembelajaran sikap. Model VCT adalah teknik pengajaran untuk membantu siswa dalam mencari dan menentukan suatu nilai yang dianggap baik dalam menghadapi suatu persoalan melalui proses menganalisis nilai yang sudah ada tertanam dalam diri siswa, sedangan kelemahan VCT yang sering terjadi dalam proses pembelajaran nilai atau sikap adalah 
proses pembelajaran dilakukan secara langsung oleh guru, artinya guru menanamkan nilai-nilai yang dianggapnya baik tanpa memperhatikan nilai yang sudah tertanam dalam diri siswa. Akibatnya, sering terjadi benturan atau konflik dalam diri siswa karena ketidakcocokan antara nilai lama yang sudah terbentuk dengan nilai baru yang ditanamkan oleh guru. Siswa sering mengalami kesulitan dalam menyelaraskan nilai lama dan nilai baru (Wina Sanjaya, 2011: 283).

Mengingat mata pelajaran PKn adalah jenis ilmu sosial-humaniora seperti pendidikan nilai moral jadi perlu adanya media juga yang bisa digunakan untuk penekanan konsep tentang nilai-moral dalam kehidupan sehari-hari. Diantara beberapa media yang ada salah satunya media video interaktif. Pada pembelajaran PKn video dapat memperkuat siswa dalam merasakan unsur emosi dan penyikapan dari pembelajaran yang efektif. Pada ranah afektif, video dapat memperkuat siswa dalam merasakan unsur emosi dan penyikapan dari pembelajaran yang efektif. Hal ini tidak dapat dilepaskan dari potensi emosional impact yang dimiliki oleh video, di mana ia mampu secara langsung merangsang sisi penyikapan personal dan sosial siswa. Membuat mereka tertawa terbahak-bahak (atau hanya tersenyum) karena gembira, atau sebaliknya menangis berurai air mata karena sedih. Dan lebih dari itu, menggiring mereka pada penyikapan seperti menolak ketidakadilan, atau sebaliknya pemihakan kepada yang tertindas. Sehingga ada pembelajaran 2 arah yang disebut dengan interaktif.

Dari paparan di atas, dapat dilihat bahwa kedua model pembelajaran tersebut memiliki kelebihan dan kelemahan masingmasing, sehingga terdapat keraguan dalam tingkat efektivitas penggunaan model pembelajaran VCT berbantu media video interaktif dan model pembelajaran ceramah berbantu media video interaktif. Jadi dalam penelitian ini, peneliti akan memfokuskan pada efektivitas penerapan pembelajaran VCT berbantu media video interaktif pada kelas eksperimen dan model konvensional ceramah berbantu media video interaktif pada kelas kontrol terhadap hasil belajar PKn kelas 5 semester II SDN Mangunsari 03.

Adapun rumusan masalah dalam penelitian ini adalah: Apakah ada perbedaan efektivitas antara model konvensional ceramah berbantu media video interaktif dan pembelajaran VCT berbantu media video interaktif terhadap hasil belajar PKn siswa kelas 5 SDN Mangunsari 03 Salatiga semester II tahun pelajaran 2014/2015.

Manfaat yang diharapkan peneliti dibagi menjadi 2 yaitu manfaat teoritis dan manfaat praktis. Adapun manfaat teoritisnya yaitu hasil penelitian diharapkan dapat mendukung dan mengokohkan teori yang berkenaan dengan pembelajaran VCT berbantu media video interaktif, dan dapat digunakan sebagai bahan pertimbangan penelitian lebih lanjut. Serta dapat meningkatkan daya kreatifitas dan inovatif sehingga diharapkan menjadi guru yang profesional. Sedangkan manfaat praktisnya adalah Sumbangan untuk lembaga pendidikan khususnya sekolah dalam usahanya meningkatkan kualitas belajar siswa. Bagi guru hasil penelitian diharapkan memberi wawasan untuk mengembangkan pembelajaran dengan menggunakan pembelajaran VCT berbantu media video interaktif dapat dilakukan dengan berkelanjutan dalam peningkatan hasil belajar siswa. Sedangkan bagi siswa hasil penelitian diharapkan dapat mengoptimalkan diri dalam belajar, serta membantu siswa dalam mencari dan menentukan suatu nilai yang dianggap baik untuk mengambil keputusan. 


\section{KAJIAN TEORI}

\section{Pendidikan Kewarganegaraan}

Berdasarkan Permendiknas No. 14 Tahun 2007 (2007:63), mata pelajaran PKn merupakan mata pelajaran yang memfokuskan pada pembentukan warga negara yang memahami dan mampu melaksanakan hakhak dan kewajibannya untuk menjadi warga negara Indonesia yang cerdas, terampil, dan berkarakter yang diamanatkan oleh Pancasila dan UUD 1945.

Ruang lingkup materi pada mata pelajaran PKn menurut Permendiknas No. 14 Tahun 2007 (2007: 63) meliputi 8 aspek, yaitu:1) Persatuan dan kesatuan bangsa, 2) Norma, hukum dan peraturan, 3) Hak asasi manusia, meliputi hak dan kewajiban anak, 4) Kebutuhan warga negara, 5) Konstitusi negara, 6) Kekuasaan dan politik, 7) Pancasila, 8) Globalisasi.

Di dalam Permendiknas No. 22 Tahun 2006 tentang standar kompetensi dan kompetensi dasar SD/MI, maka ditetapkan standar kompetensi dan kompetensi dasar untuk mata pelajaran PKn SD kelas 5 Semester II Tahun Pelajaran 2014/2015 dapat dilihat pada Tabel 1.

\section{Pembelajaran VCT}

Pembelajaran VCT adalah teknik pengajaran untuk membentuk siswa dalam mencari dan menentukan suatu nilai yang dianggap baik dalam menghadapi suatu persoalan melalui proses menganalisis nilai yang sudah ada dan tertanam dalam diri siswa (Wina Sanjaya, 2011: 283). Menurut Sutarjo Adisusilo (2012:141) "model VCT adalah pembelajaran pendidikan nilai dimana peserta didik dilatih untuk menemukan, memilih, menganalisis, memutuskan, mengambil sikap sendiri nilai-nilai hidup yang ingin diperjuangkannya". Peserta didik dibantu menjernihkan, memperjelas atau mengklarifikasikan nilai-nilai hidupnya, lewat values problem solving, diskusi, dialog dan presentasi. Misalnya peserta didik dibantu menyadari nilai hidup mana yang sebaiknya diutamakan dan dilaksanakan, lewat pembahasan kasus-kasus hidup yang sarat dengan konflik nilai atau moral.

Menurut Cheppy (Sutarjo Adisusilo, 2012:152), kekuatan pendekatan ini terutama memberikan penghargaan yang tinggi kepada peserta didik sebagai individu yang mempunyai hak dan kebebasan untuk memilih, menentukan sikap dan bertindak berdasarkan kepada nilainya sendiri. Adisusilo (2012:152) mengungkapkan bahwa VCT memiliki kelebihan diantaranya:

a. Membantu siswa untuk berproses menyadari dan mengidentifikasi nilai-

Tabel 1 Standar Kompetensi dan Kompetensi Dasar Mata Pelajaran Pendidikan Kewarganegaraan Kelas 5 Semester II Tahun Pelajaran 2014/2015

\begin{tabular}{|c|c|}
\hline Standar Kompetensi & Kompetensi Dasar \\
\hline \multirow{3}{*}{$\begin{array}{l}\text { 3. Memahami kebebasan } \\
\text { berorganisasi }\end{array}$} & 3.1 Mendeskripsikan pengertian organisasi \\
\hline & $\begin{array}{l}\text { 3.2 Menyebutkan contoh organisasi di lingkungan sekolah dan } \\
\text { masyarakat }\end{array}$ \\
\hline & 3.3 Menampilkan peran serta dalam memilih organisasi di sekolah \\
\hline \multirow{2}{*}{$\begin{array}{l}\text { 4.Menghargai keputusan } \\
\text { bersama }\end{array}$} & 4.1 Mengenal bentuk-bentuk keputusan bersama \\
\hline & 4.2 Mematuhi keputsan bersama \\
\hline
\end{tabular}


nilai mereka sendiri serta nilai-nilai orang lain.

b. Membantu siswa supaya mereka mampu berkomunikasi secara terbuka dan jujur dengan orang lain, berhubungan dengan nilai-nilainya sendiri.

c. Membantu siswa supaya mampu menggunakan secara bersama-sama kemampuan berpikir rasional dan kesadaran emosional, untuk memahami perasaan, nilai-nilai, sikap dan pola tingkah laku mereka sendiri dan akhirnya didorong untuk menghayatinya.

Sama halnya dengan pendekatan perkembangan kognitif, pendekatan ini juga mengandung kelemahan sebab dapat menampilkan bias budaya barat. Dalam pendekatan ini, kriteria benar-salah dapat relatif, karena sangat mementingkan nilai perseorangan. VCT memang dikembangkan dalam budaya barat yang cenderung amat individualistis dan liberal. Oleh sebab itu, seorang pendidik harus bijak dalam memberi pendampingan agar dalam pemilihan, penentuan nilai, peserta didik tidak tercabut dari akar budayanya.

Adapun langkah-langkah pengajaran yang menggunakan VCT. Menurut Hall dan Simon (Sutarjo Adisusilo, 2012:147) ada tiga proses klarifikasi nilai, yaitu sebagaimana pada Tabel 2.

\section{Model Konvensional Ceramah}

Metode ceramah adalah suatu bentuk metode yang dilaksanakan oleh guru dengan memberikan sejumlah informasi kepada sejumlah siswa, baik di dalam atau di luar ruangan (Soegeng Santoso dalam Etin Solihatin, 2013: 122). Menurut James Popham, metode ceramah sebagai metode mengajar dimana guru menyajikan informasi secara lisan (Etin Solihatin, 2013: 122). Kecenderungan guru menganggap metode ceramah sebagai metode pembelajaran yang paling mudah. Anggapan demikian sebenarnya kurang tepat Mc. Leish (PPPG IPS dan PMP Malang, 2006:49) memandang bahwa keberhasilan metode ceramah tergantung harapan siswa. Jika siswa menyukai, maka penggunaan metode ceramah akan berfaedah, sebaliknya jika siswa tidak menyukai, maka penggunaan metode ceramah akan menemui kegagalan. Menurut Etin Solihatin (2013:124) ada empat langkah pemakaian metode ceramah meliputi:

1. Tahap persiapan ceramah

Tahap persiapan ceramah mencakup, mengorganisasi isi pelajaran yang akan diceramahkan, mempersiapkan penguasaan isi pelajaran yang akan diceramahkan, memilih dan mempersiapkan media instruksional atau alat bantu yang akan digunakan dalam ceramah.

Tabel 2 Proses Klarifikasi Nilai

\begin{tabular}{|c|c|}
\hline 1. Memilih & $\begin{array}{l}\text { 1. Memilih dengan bebas } \\
\text { 2. Memilih dari berbagai alternatif } \\
\text { 3. Memilih berbagai alternatif setelah mengadakan pertimbangan } \\
\text { tentang berbagai akibatnya }\end{array}$ \\
\hline $\begin{array}{l}\text { 2. Menghargai / } \\
\text { menjunjung } \\
\text { tinggi }\end{array}$ & $\begin{array}{l}\text { 4. Menghargai dan merasa bahagia dengan pilihannya } \\
\text { 5. Bersedia mengakui/menegaskan pilihannya itu di depan umum }\end{array}$ \\
\hline 3. Bertindak & $\begin{array}{l}\text { 6. Berbuat/berperilaku sesuatu sesuai dengan pilihannya } \\
\text { 7. Berulang-ulang bertindak sesuai dengan pilihannya itu hingga } \\
\text { akhirnya merupakan pola hidupnya. }\end{array}$ \\
\hline
\end{tabular}




\section{Tahap awal ceramah}

Tahap awal ceramah mencakup, peningkatan hubungan guru-siswa, peningkatan perhatian siswa, mengemukakan pokokpokok isi ceramah.

3. Tahap pengembangan ceramah

Tahap pengembangan ceramah mencakup memberi keterampilan secara singkat dan jelas, mempergunakan papan tulis, menerangkan kembali dengan menggunakan istilah atau kata-kata yang yang lebih jelas, memperinci dan memperluas keadaan, memberikan balikan (feed back) sebanyak-banyaknya selama berceramah, mengatur alokasi waktu ceramah.

4. Tahap akhir ceramah

Melakukan tanya jawab dan mengadakan evaluasi untuk mengevaluasi keberhasilan proses pembelajaran.

\section{Media Video Interaktif}

Schramm (Iswidayati, 2010: 2) mengatakan media pembelajaran adalah teknologi pembawa pesan yang dapat dimanfaatkan untuk keperluan pembelajaran dan mempengaruhi efektivitas pembelajaran. Beberapa media yang dikenal dalam pembelajaran antara lain: media visual (gambar atau foto, sketsa, diagram, bagan/ chart, kartun, poster, peta dan globe, papan planel, papan buletin), media audio (radio, alat perekam magnetik atau tape recorder), media proyeksi diam (film bingkai, film rangkai, OHP (overhead projector), opaque projektor, mikrofis), media proyeksi gerak dan audio visual (film gerak, film gelang atau film loop, program tv, video), multimedia, benda.

Raharjo (Iswidayati, 2010: 15) menjelaskan kelebihan menggunakan media dalam pembelajaran. Adapun kelebihan media dalam pembelajaran antara lain:
1. Bahan pelajaran akan lebih jelas maknanya sehingga lebih jelas dipahami siswa sehingga memungkinkan siswa menguasai tujuan pengajaran lebih baik.

2. Metode mengajar akan lebih bervariasi

3. Siswa lebih banyak melakukan kegiatan belajar

4. Motivasi belajar dari pada siswa dapat ditumbuhkan/dinaikkan

5. Dapat mengatasi sifat pasif dari para siswa.

Arsyad (Rusman, 2011:218) mengemukakan "video merupakan serangkaian gambar gerak yang disertai suara yang membentuk satu kesatuan yang dirangkai menjadi sebuah alur, dengan pesan-pesan didalamnya untuk ketercapaian tujuan pembelajaran yang disimpan dengan proses penyimpanan pada media pita dan disk".

Menurut Seels dan Glasgow (Arsyad, 2002:36) media pembelajaran interaktif adalah suatu sistem penyampaian pengajaran yang menyajikan materi video rekaman dengan pengendalian komputer kepada penonton (siswa) yang tidak hanya mendengar dan melihat video dan suara, tetapi juga memberikan respon yang aktif, dan respon itu yang menentukan kecepatan dan sekuensi penyajian.

\section{Hasil Belajar}

Hasil belajar menurut Suprijono Agus (2011:7) adalah perubahan perilaku secara keseluruhan bukan hanya salah satu aspek potensi kemanusiaan saja. Sudjana (2001: 22) menegaskan bahwa hasil belajar adalah kemampuan-kemampuan yang dimiliki siswa setelah ia menerima pengalaman belajarnya. Dalam sistem pendidikan nasional, rumusan pendidikan baik tujuan kurikuler maupun tujuan instruksional menggunakan klasifikasi hasil belajar dari Benyamin Bloom yang secara garis besar membaginya menjadi tiga ranah, yaitu ranah kognitif, ranah afektif, 
dan ranah psikomotor. Menurut Oemar Hamalik (2006:30) hasil belajar adalah bila seseorang telah belajar akan terjadi perubahan tingkah laku pada orang tersebut, misalnya dari tidak tahu menjadi tahu, dan dari tidak mengerti menjadi mengerti.

Menurut Rifa'i dan Anni (2009: 85) hasil belajar merupakan perubahan perilaku yang diperoleh siswa setelah melaksanakan kegiatan belajar. Bloom dalam Rifa'i dan Anni (2009: 85) menyampaikan tiga taksonomi yang disebut dengan ranah belajar, yaitu:

1. Ranah kognitif, merupakan ranah yang berkaitan dengan hasil berupa pengetahuan, kemampuan, dan kemahiran intelektual. Ranah ini mencakup kategori: 1) pengetahuan, 2) pemahaman, 3) penerapan, 4) analisis, 5) sintesis, dan 6) penilaian.

2. Ranah afektif, merupakan ranah yang berkaitan dengan perasaan, sikap, minat, dan nilai. Kategori tujuan pembelajaran afektif yaitu: 1) penerimaan, 2) penanggapan, 3) penilaian, 4) pengorganisasian, dan 5) pembentukan pola hidup.

3. Ranah psikomotor, yaitu ranah yang berkaitan dengan kemampuan fisik seperti keterampilan motorik dan syaraf, manipulasi objek, dan koordinasi syaraf. Kategori jenis perilaku untuk ranah psikomotorik menurut Simpson (Rifa'i dan Anni 2009: 89) yaitu: 1) persepsi, 2) kesiapan, 3) gerakan terbimbing, 4) gerakan terbiasa, 5) gerakan kompleks, 6) penyesuaian, dan 7) kreativitas.

Cara mengukur hasil belajar ada dua cara, yaitu menggunakan tes (tes uraian dan tes objektif) dan nontes.

\section{Kajian Penelitian yang Relevan}

Ada beberapa penelitian yang berfokus pada pembelajaran VCT antara lain: Menurut penelitian yang dilakukan Fairizah
Haris (2013) dengan judul "Penerapan Model Pembelajaran VCT untuk meningkatkan Kesadaran Nilai Menghargai Jasa Pahlawan Pada Siswa Sekolah Dasar Negeri Semambung No. 296 Sidoarjo", disimpulkan bahwa aktivitas guru melalui penerapan model pembelajaran VCT di kelas 5 mengalami peningkatan setiap siklusnya. Hal ini ditunjukkan dengan diterapkannya langkahlangkah model pembelajaran VCT dengan lengkap. Aktivitas siswa melalui penerapan model pembelajaran VCT juga mengalami peningkatan, yang paling menonjol adalah aktivitas di analisis dan presentasi hasil diskusi kelompok. Siswa yang dulunya pasif menjadi lebih aktif dan bersemangat mengikuti pembelajaran. Hasil belajar afektif penanaman nilai terjadi pada setiap siklusnya, hal ini menunjukkan bahwa dengan menggunakan model pembelajaran VCT dapat meningkatkan kesadaran nilai menghargai jasa pahlawan. Hal ini dapat dilihat dari lembar penilaian skala sikap setiap siklusnya. Semakin banyak siswa yang mencapai skor ketuntasan minimal yang ditentukan. Peningkatan ini sesuai dengan target indikator keberhasilan yang telah dirumuskan peneliti.

Dalam E-journal Undiksha penelitian yang dilakukan Ni Pt. Yoni Rahayudhi, A. A. Gd.Agung, dan I Dw. Kade Tastra (2012) dengan judul penelitian "Pengaruh Model Pembelajaran VCT Berbantuan Media Microsoft Powerpoint Terhadap Prestasi Belajar Pkn Siswa Kelas V SD gugus II Kecamatan Tegallalang", disimpulkan bahwa (1) Deskripsi prestasi belajar PKn siswa yang dibelajarkan dengan model pembelajaan konvensional menunjukan bahwa sebagian besar skor cenderung rendah, hal ini dapat dilihat dari hasil perhitungan bahwa $\mathrm{Mo}<\mathrm{Md}<\mathrm{M}$ atau 24,30 $<26,00$ $<27,10$. Berdasarkan pedoman konversi 
penilaian skala lima berada pada kategori sedang, (2) Deskripsi prestasi belajar PKn siswa yang dibelajarkan dengan model pembelajaran Value Clarification Technique (VCT) berbantuan media Microsoft Power Point menunjukan skor cenderung tinggi, hal ini dapat dilihat dari hasil perhitungan yang menunjukkan bahwa Mo > Md > M atau 45,78 > 43,90> 42,50. Berdasarkan pedoman penilaian skala lima berada pada kategori tinggi. Dari hasil uji hipotesis yang telah dilakukan dengan menggunakan uji-t ditemukan bahwa terdapat perbedaan yang signifikan model pembelajaran VCT berbantuan media Microsoft PowerPoint terhadap prestasi belajar PKn siswa diketahui bahwa t hitung $>\mathrm{t}$ tabel $(9,23>2,00$ dengan taraf signifikansi 5\%).

Menurut penelitian yang dilakukan Imaniar Purbasari (2012) dengan judul "Pengaruh Model Pembelajaran VCT(Value Clarification Technique) terhadap Pemahaman Nilai Tradisi Sejarah Siswa Kelas X Sekolah Menengah Atas Negeri di Kabupaten Kudus Tahun Pelajaran 2011/2012 Ditinjau dari Kecerdasan Emosional", disimpulkan bahwa model pembelajaran VCT dan ekspositori dapat mempengaruhi secara signifikan terhadap pemahaman nilai tradisi masa praaksara dan aksara siswa SMA Negeri Kabupaten Kudus.

\section{Hipotesis Penelitian}

Berdasarkan kajian teori, kajiankajian penelitian yang relevan dan kerangka pikir, peneliti merumuskan hipotesis alternatif sebagai berikut : ada perbedaan efektivitas model konvensional metode ceramah berbantu media video interaktif dan pembelajaran VCT berbantu media video interaktif terhadap hasil belajar PKn kelas 5 SDN Mangunsari 03 Salatiga semester II tahun pelajaran 2014/2015. Sedangkan hipotesis nol dari penelitian ini adalah tidak ada perbedaan efektivitas model konvensional metode ceramah berbantu media video interaktif dan pembelajaran VCT berbantu media video interaktif terhadap hasil belajar PKn kelas 5 SDN Mangunsari 03 Salatiga semester II tahun pelajaran 2014/2015.

\section{METODE PENELITIAN}

\section{Jenis dan Lokasi Penelitian}

Jenis penelitian yang digunakan dalam penelitian ini adalah eksperimen dengan metode penelitian quasi eksperimental. Desain penelitian yang digunakan adalah pretest-posttest control group design.

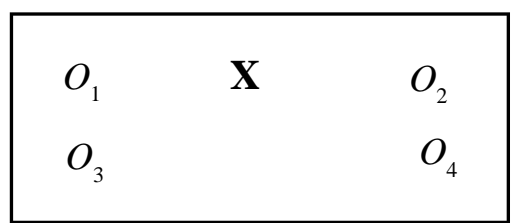

Gambar 1 Desain penelitian pretest-posttest control group design

\section{Variabel Penelitian}

Variabel dalam penelitian ini ada dua yaitu pembelajaran VCT berbantu video interaktif sebagai variabel bebas dan hasil belajar PKn sebagai variabel terikat.

\section{Unit Penelitian}

Populasi adalah wilayah generalisasi yang terdiri atas objek/subjek yang mempunyai kualitas dan karakteristik tertentu yang ditetapkan oleh peneliti untuk dipelajari dan kemudian ditarik kesimpulannya (Sugiyono, 2010:117). Populasi dalam penelitian ini adalah siswa SD Negeri Mangunsari 03 dan SD Negeri Mangunsari 07 yang masingmasing berjumlah 215 siswa dan 250 siswa.

\section{Teknik dan Instrumen Pengumpulan Data}

Teknik Pengumpulan data ada 2 yaitu dengan menggunakan tes dan observasi. 
Teknik analisis data menggunakan validitas instrumen, reliabilitas instrumen, uji homogenitas, uji normalitas, uji deskriptif, uji hipotesis dengan uji $t$ tes.

Validitas dan reliabilitas dilakukan untuk menguji kevalidan dan reliabilitas instrumen agar hasil yang diharapkan sesuai valid dan sesuai dengan tujuan pembelajaran.

Uji homogenitas digunakan untuk mengetahui apakah beberapa varian populasi data adalah sama atau tidak. Uji ini dilakukan sebagai prasyarat dalam analisis Independent Sample T Test atau One Way ANONA. Asumsi yang mendasari dalam analisis varian (ANOVA) adalah bahwa varian dari populasi adalah sama. Sebagai kriteria pengujian, jika nilai signifikan lebih dari 0,05 maka dapat dikatakan varian dari dua atau lebih kelompok data adalah sama.

Uji normalitas dilakukan untuk mengetahui normal atau tidaknya sebaran data yang akan dianalisis dan uji homogenitas untuk memastikan kelompok data berasal dari populasi yang homogen. Uji normalitas menggunakan uji KolmogrovSminov. Kriterianya adalah signifikansi hasil perhitungan lebih besar dari $>0,05$.

Analisis deskriptif digunakan untuk menganalisis sejumlah data yang dikumpulkan dalam penelitian ini, sehingga diperoleh gambaran mengenai keadaan suatu variabel yang diteliti melalui data sampel atau popu- adalah modus, median, mean, standar deviasi, rentang skor, frekuensi dan prosentase.

Uji hipotesis adalah pengujian yang bertujuan untuk mengetahui apakah kesimpulan pada sampel dapat berlaku untuk populasi (dapat digeneralisasikan). Dalam penelitian ini yang digunakan adalah uji Independent samples T Test. Uji Independent samples T Test digunakan untuk mengetahui ada atau tidaknya perbedaan rata-rata antara dua kelompok sampel yang tidak berhubungan. Sebelum dilakukan uji t test (Independent samples T Test) sebelumnya diuji kesamaan varian (homogenitas) dengan $\mathrm{f}$ test (Levene, $s$ Test), artinya jika varian sama, maka uji $\mathrm{t}$ menggunakan Equal variaces Assumed (diasumsikan varian sama) jika varian berbeda menggunakan Equal Variances Not Assumed (diasumsikan varian berbeda).

\section{HASIL PENELITIAN DAN PEMBAHASAN}

\section{Hasil Penelitian}

Data hasil penelitian diperoleh dari skor hasil evaluasi posttest yang telah dilakukan oleh peneliti pada kelas eksperimen dan kelas kontrol yang dideskripsikan dalam bentuk diagram garis. Berikut ini gambaran skor hasil belajar PKn kelas eksperimen yang disajikan pada Gambar 2. lasi sebagaimana adanya (Sugiyono, 2010: 207). Analisis deskriptif dalam penelitian ini digunakan untuk mengetahui gambaran mengenai hasil pengukuran variabel pretestpostest pada kelas kontrol dan eksperimen dan hasil belajar. Ukuran yang digunakan dalam penelitian ini

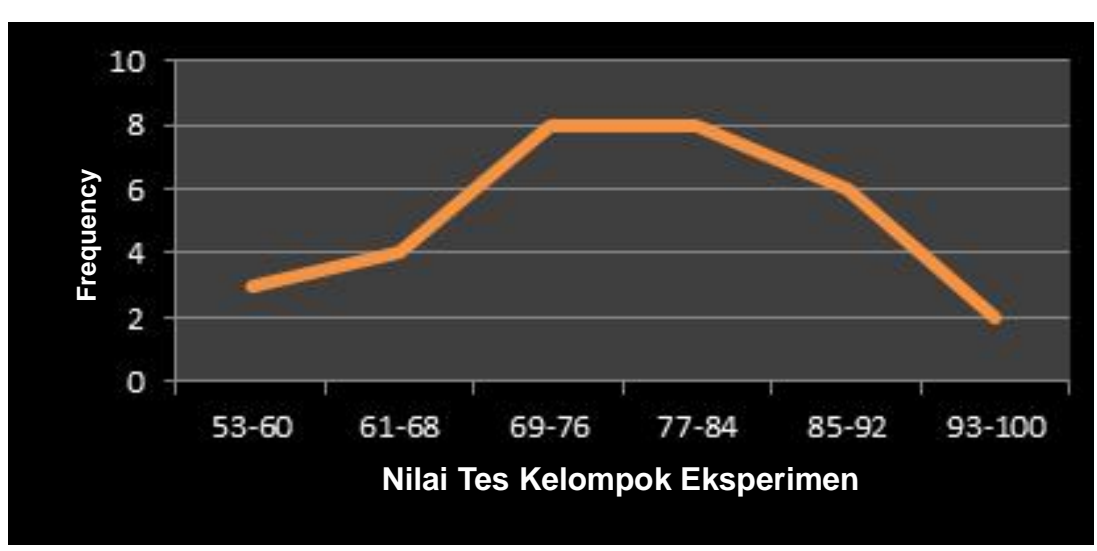

Gambar 2 Diagram Garis Skor Hasil Belajar PKn Kelas Eksperimen 
Berdasarkan gambar 2 dapat dilihat bahwa skor hasil belajar PKn kelas eksperimen seluruh siswa kelas $5 \mathrm{SDN}$ Mangunsari 03. Siswa yang mendapat skor 53 sampai 60 terdiri atas 3 siswa. Siswa yang mendapat skor antara 61 sampai 68 terdapat 4 siswa, siswa yang mendapat skor 69 sampai 76 terdiri dari 8 siswa, begitupun dengan skor 77 sampai 84 juga terdiri dari 8 siswa, lalu siswa yang mendapatkan skor 85-92 terdiri dari 6 anak. Kemudian untuk skor yang teringgi yaitu 93 sampai 100 hanya terdapat 2 siswa dari 31 siswa yang ada di kelas 5 SDN Mangunsari 03.

Berikut ini gambaran skor hasil belajar PKn kelas kontrol yang disajikan pada Gambar 3.

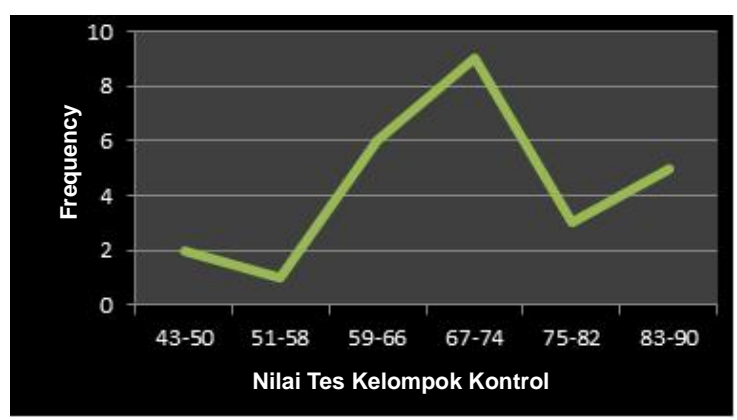

Gambar 3 Diagram Garis Skor Hasil Belajar PKn Kelas Kontrol

Berdasarkan gambar 3 dapat diketahui skor hasil belajar PKn kelas kontrol seluruh siswa kelas 5 SDN Mangunsari 07. Siswa yang mendapatkan skor 43 sampai 50 terdapat 2 siswa, siswa yang mendapatkan skor 51 sampai 58 terdapat 1 siswa, siswa yang mendapatkan skor 59 sampai 66 terdapat 6 siswa, kemudian siswa yang mendapatkan skor 67 sampai 74 ini yang terbanyak yaitu terdapat 9 siswa, lalu siswa yang mendapatkan skor 75 sampai 82 terdapat 3 siswa, kemudian skor yang tertinggi yaitu 83-90 terdapat 5 siswa. Setelah disajikan dalam diagram garis, data diolah menggunakan analisis deskriptif yang tersaji pada Tabel 3.

Dari Tabel 3 dapat dilihat bahwa hasil belajar PKn kelas eksperimen dengan jumlah data $(\mathrm{N})$ sebanyak 31 mempunyai nilai minimum 53,00 dan nilai maximum 98,00 . Sedangkan rata-rata/mean pada kelas eksperimen yaitu 77,0645 dan standart deviation yaitu 10,76084. Sedangkan hasil belajar PKn pada kelas kontrol dengan jumlah data $(\mathrm{N})$ sebanyak 26 mempunyai nilai minimum 43,00 dan nilai maximum 90,00. Rata-rata/mean pada kelas kontrol yaitu 70,9231. Sedangkan standart deviation yaitu 11,59629.

Analisis data selanjutnya adalah uji normalitas dengan melihat pada kolom Kolmogrov-Smirnov dapat diketahui skor signifikasi untuk hasil belajar PKn kelas eksperimen dan kelas kontrol sebesar 0,200 $>0,05$, maka dapat disimpulkan bahwa data berdestribusi normal.

Setelah data dinyatakan normal, selanjutnya dilakukan uji homogenitas. Uji homogenitas dapat diketahui dengan membaca angka Levene Statistic menunjukkan 0,144, semakin kecil nilainya maka semakin besar homogenitasnya. Kemudian df1= jumlah kelompok data -1 atau 2-1 = 1 sedangkan df2 = jumlah data-jumlah kelompok data atau 57-2 = 55. Dari output tersebut dapat diketahui signifikansi sebesar

Tabel 3 Analisis Deskriptif Skor Hasil Belajar PKn Kelas Eksperimen dan Kelas Kontrol Tahun Pelajaran 2014/2015

Descriptive Statistics

\begin{tabular}{lccccc}
\hline & N & Minimum & Maximum & Mean & Std. Deviation \\
\hline Eksperimen & 31 & 53.00 & 98.00 & 77.0645 & 10.76084 \\
Kontrol & 26 & 43.00 & 90.00 & 70.9231 & 11.59629 \\
Valid N (listwise) & 26 & & & & \\
\hline
\end{tabular}


0,706. Maka dapat disimpulkan bahwa kedua variansi adalah sama (varian kelas eksperimen dengan kelas kontrol).

Selanjutnya analisis yang terakhir yaitu Uji Independent Sample T-Test. Uji ini digunakan sebagai pengambilan keputusan dalam menentukan apakah Ho ditolak atau Ha diterima. Berikut tabel hasil uji t test. dari kelas eksperimen dan kelas kontrol. Pada Group Statistik terlihat rata-rata (mean) untuk kelas eksperimen adalah 77,0645 dan untuk kelas kontrol adalah 70,9231, artinya bahwa rata-rata skor hasil belajar PKn kelas eksperimen lebih tinggi daripada rata-rata skor hasil belajar PKn kelas kontrol. Sedangkan perbedaan rata-rata (mean

Tabel 4 Hasil Uji t Skor Hasil Belajar PKn Kelompok Eksperimen dan Kelompok Kontrol Tahun Pelajaran 2014/2015

\begin{tabular}{|c|c|c|c|c|c|c|c|c|c|c|}
\hline & & \multicolumn{2}{|c|}{$\begin{array}{l}\text { Levene's Test } \\
\text { for Equality of } \\
\text { Variances }\end{array}$} & \multicolumn{7}{|c|}{ t-test for Equality of Means } \\
\hline & & \multirow[t]{2}{*}{$\mathrm{F}$} & \multirow[t]{2}{*}{ Sig. } & \multirow[t]{2}{*}{$\mathrm{t}$} & \multirow[t]{2}{*}{ df } & \multirow[t]{2}{*}{$\begin{array}{c}\text { Sig. } \\
\text { (2-tailed) }\end{array}$} & \multirow[t]{2}{*}{$\begin{array}{c}\text { Mean } \\
\text { Difference }\end{array}$} & \multirow[t]{2}{*}{$\begin{array}{l}\text { Std. Error } \\
\text { Difference }\end{array}$} & \multicolumn{2}{|c|}{$\begin{array}{l}95 \% \text { Confidence } \\
\text { Interval of the } \\
\text { Difference }\end{array}$} \\
\hline & & & & & & & & & Lower & Upper \\
\hline \multirow[t]{2}{*}{ posttest } & $\begin{array}{l}\text { Equal } \\
\text { variances } \\
\text { assumed }\end{array}$ & .144 & .706 & 2.072 & 55 & .043 & 6.14144 & 2.96470 & .20005 & 12.08283 \\
\hline & $\begin{array}{l}\text { Equal } \\
\text { variances not } \\
\text { assumed }\end{array}$ & & & 2.058 & 51.685 & .045 & 6.14144 & 2.98453 & .15167 & 12.13120 \\
\hline
\end{tabular}

Dari hasil Tabel 4 dapat dilihat pada baris equal variances assumed karena varian data sama (homogen), ini dapat dilihat dari kolom sig yang menunjukkan angka 0,706 $(0,706>0,05)$ dan signifikansi pada hasil T-test terlihat pada kolom sig (2-tailed) menunjukkan angka 0,043. Pada kolom mean different nampak bahwa perbedaan rata-rata sebesar 6,14144 (77,0645-70,9231) dan perbedaan berkisar antara 0,20005 sampai 12,08283 sebagaimana dapat dilihat di kolom lower dan upper.

\section{Pembahasan}

Pembahasan hasil penelitian ini memaparkan dan mengaitkan hasil analisis data, uji hipotesis yang telah diuraikan sebelumnya dengan kajian teori dan penelitian yang telah dilakukan oleh peneliti terdahulu. Berdasarkan analisis data yang sudah dilakukan terlihat perbedaan rata-rata deference) sebesar 6,1414 (77,0645 70,9231), dan perbedaan berkisar antara 0,20005 sampai 12,08283 terlihat pada lower dan upper. Hasil belajar PKn kelas eksperimen dengan jumlah siswa 31 mempunyai nilai terendah 53,00 dan nilai tertinggi 98,00. Sedangkan hasil belajar PKn pada kelas kontrol dengan jumlah siswa sebanyak 26, mempunyai nilai terendah 43,00 dan nilai tertinggi 90,00. Oleh karena itu dapat diketahui t hitung sebesar 2,072 dan signifikansi sebesar 0,043. Hal ini menunjukkan $t$ hitung lebih besar dari pada t tabel yakni 2,00404 (2,072 > 2,00404) dan signifikansi lebih kecil dari 0,05 (0,043< 0,05). Maka Ho ditolak dan Ha diterima. Itu artinya hipotesis Ada perbedaan efektivitas dalam penggunaan model pembelajaran VCT berbantu media video interaktif dengan model konvensional metode ceramah berbantu media video interaktif terhadap hasil 
belajar PKn semester II kelas 5 SDN Mangunsari 03 Salatiga tahun pelajaran 2014/2015 diterima.

Perbedaan efektivitas ini dilihat dari hasil uji t dan perbedaan rata-rata dua kelas. $\mathrm{Hal}$ ini berarti pembelajaran dengan model VCT berbantu media video interaktif lebih efektif dari pada pembelajaran model konvensional ceramah berbantu media video interaktif. Berdasarkan hasil penelitian, ada perbedaan efektivitas antara penerapan pembelajaran VCT berbantuan video interaktif dengan penerapan pembelajaran konvensional ceramah berbantuan video interaktif terhadap hasil belajar PKn siswa kelas 5 SDN Mangunsari 03 dan SDN Mangunsari 07 semester genap Tahun Pelajaran 2014/2015.

Hal ini bisa disebabkan oleh berbagai hal, antara lain: menurut Sutarjo Adisusilo (2012:141) "model VCT adalah pembelajaran pendidikan nilai dimana peserta didik dilatih untuk menemukan, memilih, menganalisis, memutuskan, mengambil sikap sendiri nilainilai hidup yang ingin diperjuangkannya". Peserta didik dibantu menjernihkan, memperjelas atau mengklarifikasikan nilai-nilai hidupnya, lewat values problem solving, diskusi, dialog dan presentasi. Misalnya peserta didik dibantu menyadari nilai hidup mana yang sebaiknya diutamakan dan dilaksanakan, lewat pembahasan kasuskasus hidup yang sarat dengan konflik nilai atau moral. Seperti yang dikemukakan oleh Amri dan Ahmadi (2010:208) bahwa strategi pembelajaran afektif sebagai strategi yang tidak hanya bertujuan untuk mencapai pendidikan kognitif saja, tetapi juga bertujuan untuk mencapai dimensi yang lainnya yaitu sikap dan keterampilan afektif. Selain itu Hall (Sutarjo Adisusilo, 2012:145) mengartikan teknik klarifikasi nilai (VCT) sebagai berikut:
By value clarification we mean a methodology or process by which we help a person to discover values through behavior, feelings, ideas, and through important choices he has made and is continually, in fact, acting upon in and through his life.

Dengan klarifikasi nilai, peserta didik tidak disuruh menghafal dan tidak "disuapi” dengan nilai-nilai yang sudah dipilihkan pihak lain, melainkan dibantu untuk menemukan, menganalisis, mempertanggungjawabkan, mengembangkan, memilih, mengambil sikap dan mengamalkan nilai-nilai hidupnya sendiri.

Faktor lain yang juga berpengaruh yaitu video interaktif. Menurut Schramm (Iswidayati, 2010: 2) mengatakan media pembelajaran adalah teknologi pembawa pesan yang dapat dimanfaatkan untuk keperluan pembelajaran dan mempengaruhi efektivitas pembelajaran. Beberapa media yang dikenal dalam pembelajaran antara lain : media visual (gambar atau foto, sketsa, diagram, bagan/chart, kartun, poster, peta dan globe, papan planel, papan buletin), media audio (radio, alat perekam magnetik atau tape recorder), media proyeksi diam (film bingkai, film rangkai, OHP (overhead projector), opaque projektor, mikrofis), media proyeksi gerak dan audio visual (film gerak, film gelang atau film loop, program tv, video), multimedia, benda.

Menurut Kemp \& Dayton (Arsyad, 2001:19) media pembelajaran memiliki tiga fungsi utama apabila media itu digunakan untuk perorangan dan kelompok yang pendengarnya dalam jumlah besar, yaitu 1) memotivasi minat atau tindakan 2) menyajikan informasi 3) memberi instruksi. Sedangkan Menurut Seels dan Glasgow (Arsyad, 2002:36) media pembelajaran interaktif adalah suatu sistem penyampaian 
pengajaran yang menyajikan materi video rekaman dengan pengendalian komputer kepada penonton (siswa) yang tidak hanya mendengar dan melihat video dan suara, tetapi juga memberikan respon yang aktif, dan respon itu yang menentukan kecepatan dan sekuensi penyajian.

Faktor lainnya juga terdapat pada antusias dan motivasi guru dalam melakukan treatment. Terlihat pada hasil observasi keterlaksanaan guru dalam melakukan langkah-langkah pembelajaran sesuai sintaks mencapai $89,5 \%$ dan juga siswa terlihat bersemangat dalam mengikuti pembelajaran tersebut.

Selain membuktikan teori dan pendapat para ahli di atas, penelitian ini juga sejalan dengan kajian penelitian relevan yang telah dilakukan peneliti terdahulu yang dimuat dalam E-journal Undiksha yang dilakukan oleh Ni Pt. Yoni Rahayudhi, A. A. Gd.Agung, dan I Dw. Kade Tastra (2012) dengan judul penelitian "Pengaruh Model Pembelajaran VCT Berbantuan Media Microsoft Powerpoint Terhadap Prestasi Belajar Pkn Siswa Kelas V SD gugus II Kecamatan Tegallalang", disimpulkan bahwa (1) Deskripsi prestasi belajar PKn siswa yang dibelajarkan dengan model pembelajaan konvensional menunjukkan bahwa sebagian besar skor cenderung rendah, hal ini dapat dilihat dari hasil perhitungan bahwa $\mathrm{Mo}<\mathrm{Md}<\mathrm{M}$ atau 24,30 < 26,00 $<27,10$. Berdasarkan pedoman konversi penilaian skala lima berada pada kategori sedang, (2) Deskripsi prestasi belajar PKn siswa yang dibelajarkan dengan model pembelajaran Value Clarification Technique (VCT) berbantuan media Microsoft Power Point menunjukkan skor cenderung tinggi, hal ini dapat dilihat dari hasil perhitungan yang menunjukkan bahwa $\mathrm{Mo}>\mathrm{Md}>$ $\mathrm{M}$ atau 45,78 > 43,90 > 42,50. Berdasarkan pedoman penilaian skala lima berada pada kategori tinggi. Dari hasil uji hipotesis yang telah dilakukan dengan menggunakan uji-t ditemukan bahwa terdapat perbedaan efektifitas model pembelajaran VCT berbantuan media Microsoft PowerPoint terhadap prestasi belajar PKn siswa diketahui bahwa $\mathrm{t}$ hitung $>\mathrm{t}$ tabel $(9,23>2,00$ dengan taraf signifikansi 5\%).

Penelitian lain yang juga menunjukkan hasil senada dengan penelitian ini adalah penelitian yang dilakukan oleh Fairizah Haris (2013) dengan judul "Penerapan Model Pembelajaran VCT untuk meningkatkan Kesadaran Nilai Menghargai Jasa Pahlawan Pada Siswa Sekolah Dasar Negeri Semambung No. 296 Sidoarjo", disimpulkan bahwa aktivitas guru melalui penerapan model pembelajaran VCT di kelas 5 mengalami peningkatan setiap siklusnya. Hal ini ditunjukkan dengan diterapkannya langkah-langkah model pembelajaran VCT dengan lengkap. Aktivitas siswa melalui penerapan model pembelajaran VCT juga mengalami peningkatan, yang paling menonjol adalah aktivitas di analisis dan presentasi hasil diskusi kelompok. Siswa yang dulunya pasif menjadi lebih aktif dan bersemangat mengikuti pembelajaran. Hasil belajar afektif penanaman nilai terjadi pada setiap siklusnya, hal ini menunjukkan bahwa dengan menggunakan model pembelajaran VCT dapat meningkatkan kesadaran nilai menghargai jasa pahlawan. Hal ini dapat dilihat dari lembar penilaian skala sikap setiap siklusnya. Semakin banyak siswa yang mencapai skor ketuntasan minimal yang ditentukan. Peningkatan ini sesuai dengan target indikator keberhasilan yang telah dirumuskan peneliti. 


\section{SIMPULAN}

Berdasarkan hasil penelitian dan pembahasan maka dapat disimpulkan bahwa ada perbedaan efektivitas antara pembelajaran VCT berbantu media video interaktif pada kelas eksperimen dan model konvensional ceramah berbantu media video interaktif pada kelas kontrol terhadap hasil belajar PKn siswa kelas 5 SDN Mangunsari 03 Salatiga semester II tahun pelajaran 2014/2015. Hal tersebut diperoleh berdasarkan hasil uji $\mathrm{t}$, yang ditunjukkan $\mathrm{t}$ hitung sebesar 2,072 dan signifikansi sebesar 0,043. Hal ini menunjukkan $t$ hitung lebih besar dari pada t tabel yakni 2,00404 (2,072 $>2,00404)$ dan signifikansi lebih kecil dari $0,05(0,043<0,05)$. Maka Ho ditolak dan Ha diterima.

Berdasarkan analisis data yang sudah dilakukan terlihat juga perbedaan rata-rata dari kelas eksperimen dan kelas kontrol. Pada Group Statistik terlihat rata-rata (mean) untuk kelas eksperimen adalah 77,0645 dan untuk kelas kontrol adalah 70,9231, artinya bahwa rata-rata skor hasil belajar PKn kelas eksperimen lebih tinggi daripada rata-rata skor hasil belajar PKn kelas kontrol. Sedangkan perbedaan rata-rata (mean deference) sebesar 6,1414 (77,0645 $70,9231)$, dan perbedaan berkisar antara 0,20005 sampai 12,08283 terlihat pada lower dan upper. Hasil belajar PKn kelas eksperimen dengan jumlah siswa 31 mempunyai nilai terendah 53,00 dan nilai tertinggi 98,00. Sedangkan hasil belajar PKn pada kelas kontrol dengan jumlah siswa sebanyak 26 , mempunyai nilai terendah 43,00 dan nilai tertinggi 90,00. Hal ini berarti penerapan pembelajaran VCT berbantu video interaktif lebih efektif.

\section{DAFTAR PUSTAKA}

Adisusilo J. R. Sutarjo. 2012. Pembelajaran Nilai Karakter. Jakarta: PT Raja Grafindo Persada.

BSNP. 2007. Pedoman Penilaian Hasil Belajar di Sekolah Dasar. Jakarta: Depdiknas

Pusat Pengembangan Penataran Guru IPS dan PMP Malang. 2006. Pendekatan, Strategi, dan Metode Pembelajaran. Malang: PPPG IPS dan PMP.

Republik Indonesia. 2003. Undang Undang Nomer 20 Tahun 2003 Tentang Sistem Pendidikan Nasional. Jakarta: Sekretariat Negara.

Rifa'i, Achmad dan Catharina Tri Anni. 2009. Psikologi Pendidikan. Semarang: Unnes Press.

Rusman, dkk. 2011. Pembelajaran Berbasis Teknologi Informasi dan Komunikasi Mengembangkan Profesionalitas Guru. Jakarta: PT Raja Grafindo Persada.

Solihatin, Etin. 2013. Strategi Pembelajaran Ppkn. Jakarta: PT Bumi Aksara.

Sudjana, Nana. 2001. Penelitian dan Penilaian Pendidikan. Bandung: Sinar Baru.

Sugiyono. 2010. Metode Penelitian Pendidikan Penelitian Kuantitatif, Kualitatif dan $R \& D$. Bandung: Alfabeta.

Suprijono, Agus. 2011. Cooperative Learning Teori dan Aplikasi Paikem. Yogyakarta: Pustaka Pelajar.

Wina Sanjaya. 2011. Strategi Pembelajaran Berorientasi Standar Proses Pendidikan. Jakarta:

Depdiknas. 2007. Permendiknas Ri Nomor 14 Tahun 2007 Tentang Standar Proses. Jakarta: DEPDIKNAS. 
Iswidayati, Sri. 2010. Pemanfaatan Media Pembelajaran Seni Budaya. Semarang: Unnes.

Arsyad, Azhar. 2002. Media Pembelajaran. Jakarta: Raja Grafindo Persada.

Imaniar Purbasari. 2012. Pengaruh Model Pembelajaran VCT(Value Clarification Technique) Terhadap Pemahaman Nilai Tradisi Sejarah Siswa Kelas X Sekolah Menengah Atas Negeri Di Kabupaten Kudus Tahun Pelajaran 2011/2012 Ditinjau Dari Kecerdasan Emosional. Tesis. Surakarta: Universitas Sebelas Maret.
Rahayudhi, Ni Pt. Yoni A. A. Gd.Agung, dan I Dw. Kade Tastra. 2012. "Pengaruh Model Pembelajaran Vct Berbantuan Media Microsoft Powerpoint Terhadap Prestasi Belajar Pkn Siswa Kelas V SD Gugus Ii Kecamatan Tegallalang". Pusat Publikasi Jurnal Universitas Pendidikan Ganesha Jurusan PGSD FIP. 1:2-10

Fairizah Haris. 2013. "Penerapan Model Pembelajaran VCT Untuk Meningkatkan Kesadaran Nilai Menghargai Jasa Pahlawan Pada Siswa Sekolah Dasar Negeri Semambung No. 296 Sidoarjo". E-Journal Unesa Jurusan Penelitian PGSD FIP. Vol. 1 No.2. 